\title{
Diversity, distribution and host range of mistletoe in protected and unprotected areas of Central Nepal Himalayas
}

\author{
M.P. Devkota ${ }^{1 *}$, G.P. Joshi ${ }^{1}$ and P. Parajuli ${ }^{1}$
}

\begin{abstract}
Diversity, distribution and host range of mistletoe were assessed in protected and unprotected areas of the Central Nepal Himalayas. This study recorded ten mistletoe species. Occurrence of all ten mistletoe species within the Shivpuri Nagarjun National Park (SNNP) was a clear indication that national parks provide better habitat for mistletoe species richness and thus a better opportunity for biodiversity conservation than in unprotected areas. For these mistletoes, a total of 34 host species of 21 unrelated families were documented. Scurrula genus of the Loranthaceae family had the hightest number of species, the highest number of host species, and the widest altitudinal distribution. Variation in climatic factors, edge effect, disperser behaviour, fragmented forests and the availability of suitable host species determine the occurrence of a particular mistletoe species in a particular habitat.
\end{abstract}

Key words: Diversity, distribution, host range, mistletoe, Nepal

$\mathbf{M}$ stletoes are a highly specialized and successful group of flowering plants that exploit and (or) parasitize a wide range of host plants. They occur over a broad range of habitats all over the world. Despite their harmful effects on the host plants, mistletoes have been considered as important components of plant diversity and forest ecosystems throughout the world (Kujit, 1964; Hawksworth, 1983; Calder, 1983; Polhill and Wiens 1998). Despite their large geographical distribution, the Old World mistletoes have been studied little. Nepal is no exception to this; as a result, there is an amazing gap of knowledge on the mistletoes of Nepal Himalayas, a biogeographically interesting transition zone between Eastern and Western Himalayan flora (Stearn, 1960). After adding five new, previously unrecorded, mistletoe species to the Flora of Nepal by Devkota and Glatzel (2005); Devkota and Koirala (2005) and Devkota and Joshi (2008), the inventory has been enriched from fifteen to twenty species. Devkota and Acharya (1996) reported 46 host species of mistletoes belonging to 25 families in Kathmandu Valley; Devkota and Glatzel (2005) documented 95 host species belonging to 45 families in the Annapurna Region and 69 host species of 38 families were recorded by Devkota and Kunwar (2006) from Godawari-Phulchowki area of Kathmandu Valley in Central Nepal.
Along with host species, the climatic factors also govern the mistletoe species diversity and distribution (Hawksworth, 1959; Ganguly and Kumar, 1976; Zakaullah and Khan, 1982; Xiao and $\mathrm{Pu}, 1988$ ). Similarly, edge effect plays a significant role in mistletoe distribution as Lopez et al. (2002); Kujit (1964); Polhill and Wiens (1998); Bach et al. (2005); and Devkota and Glatzel (2005) have reported that fragmented marginal forests had more adult mistletoe plants than the inner forest. Landscape modification and habitat fragmentation are key drivers that affect mistletoe growth and distribution (Kelly et al., 2000), and the limited degree of forest fragmentation improves reproduction in endemic mistletoes (Lavorel et al., 1999) by promoting invasion. Kujit (1964) reported that the occurrence of some mistletoe at higher elevation is limited by environmental factors and is not related to host preference. Abulfatih and Emara (1988) recorded mistletoes restricted to its specific host between 2000-2400 m. Unlike these observations, Kujit (1969) suggested the importance of bird's behaviour and concluded that distribution of mistletoe entirely depends upon the habits of the birds that disseminate the seeds.

This study attempts to explore and compare mistletoe diversity in protected and unprotected areas

Botany Department, Amrit Campus, Tribhuvan University, Kathmandu, Nepal.

Author for correspodence: mdevkota@wlink.com.np 
in the Central Himalayas of Nepal. The results of the study will supplement information on Nepalese mistletoe diversity, host range and distribution. As a spin-off, by documenting of mistletoes in the threatened ecosystems of Central Region of Nepal, a biodiversity hotspot, the study will greatly contribute to the conservation of mistletoes.

\section{Materials and methods}

\section{Study area}

The study was carried out in two national parks: Langtang National Park (LNP) and Shivpuri Nagarjun National Park (SNNP) in the Central Nepal Himalayas. Both parks provide a great diversity of vegetation types ranging from hot sub-tropical to sub-alpine, with changes in elevation and climate on the northern and southern slopes of the great Mahabharat Mountain Range. SNNP $\left(159 \mathrm{~km}^{2}\right)$ is situated at the northern boundary of the Kathmandu valley and lies in the transition zone between subtropical and temperate climates. Depending on altitude and aspect, the vegetation consists of a variety of natural forest types including pine, oak, and rhododendron. The southern slopes of SNNP consists of Schima-Castanopsis forest and Pinus wallichiana forest below $1800 \mathrm{~m}$, whereas Alnus nepalensis is the prevalent tree species along the streams. At higher elevations, various species of oaks and rhododendron dominate the vegetation.

LNP $\left(1710 \mathrm{~km}^{2}\right)$ represents a meeting point between Indo-Malayan and Paleartic realms. Elevational gradient (ranging from mid hills to alpine) coupled with complex topography and geology have produced a rich biodiversity and a unique patchwork of vegetation. Sub-tropical vegetation is characterized by dominant tree species, Shorea robusta, under Dipterocarpaceae family on the southern flank of the park which is gradually replaced by the hill forest (2000-2600 m) consisting of Pinus roxburghii, Rhododendron arboreum, Schima-Castanopsis and Alnus nepalensis. The temperate zone $(2600-3000 \mathrm{~m})$ is dominated by oak forest (Quercus semecarpifolia) fading to old growth forest of Tsuga dumosa, Abies spectabilis, Betula utilis, Juniperus indica, J. recurva and Larix bimalaica in the lower sub-alpine zone (3000-3600 m). Further up, the vegetation is dominated by thickets and shrubs consisting of Betula utilis and R. campanulatum.

The explored area outside protected area lies between two national parks starting from Magingoth (3220 m) and passing through Kutumsang (2470 m),
Gulbhajyang $(2130 \mathrm{~m})$ and ending at Chisapani (2215 m) (Fig 1). This segment of trekking route passes through settlements and agriculture land with extensive farming practices.

\section{Mistletoe inventory}

A mistletoe inventory was carried out along the trekking route starting at Dhunche of LNP and ending at Sundarijal of SNNP passing through great altitudinal variation and different vegetation types (Fig. 1).

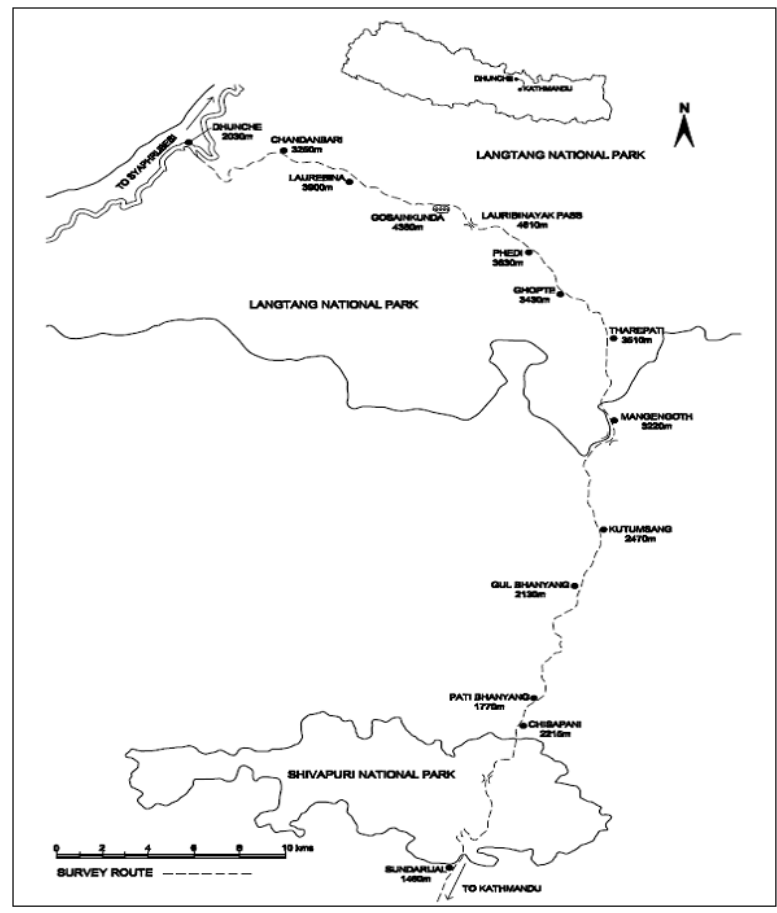

Fig 1: Study area showing two national parks and survey route

Mistletoes were explored for ten days in April 2007. Representative areas of various forest types and habitats were visited along the trekking route to uncover mistletoe diversity and host species within the protected and unprotected areas. Forest trails developed by local people were used to explore a maximum possible area, representing different forest types at different elevations. Undisturbed to moderately disturbed forests and degraded marginal forests along with community forests, orchards and vegetations surrounding agricultural fields were also explored. Occurrence of all mistletoe species with their respective hosts were recorded along with the ecological features of habitat such as altitude, slope direction, availability of light and moisture, forest type, and phenology during the inventory.

Standard sized mistletoe specimens were collected carefully without endangering their local population, 
and herbaria were prepared. Collected mistletoe specimens and host species were identified with the help of herbaria deposited at National Herbarium at Kathmandu and confirmed with the help of field notes and other standard literature (Hara et al., 1978, 1979, 1982; Malla et al., 1976; Koba et al., 1994; Press et al., 2000). The International Plant Name Index (http://www.ipni.org) was accessed for the taxonomic nomenclature of mistletoe and host species.

\section{Results and discussion}

\section{Mistletoe diversity and host range}

A total of ten mistletoe species, eight belonging to five genera in the family Loranthaceae (Macrosolen, Taxillus, Helixanthera, Scurrula, and Loranthus) and two belonging to one genus in the family Viscaceae (Viscum) were recorded in the study area. These ten mistletoe species were parasitizing 34 host plants belonging to 28 genera of 21 unrelated host families (Table 1).

Protected areas revealed higher mistletoe species diversity than the unprotected areas. Highest mistletoe species diversity was found in SNNP as all ten mistletoe species were recorded in a smaller national park than LNP (Fig 2). Only five mistletoe species were recorded along the trekking route between Dhunche to Magingoth within LNP. This number was higher than the species number reported in the Flora of Langtang (Malla et al., 1976). Surprisingly, six mistletoe species, higher than in LNP, were recorded along the trekking route passing through the settlements and agriculture fields between Kutumsang and Chisapani in the unprotected area.

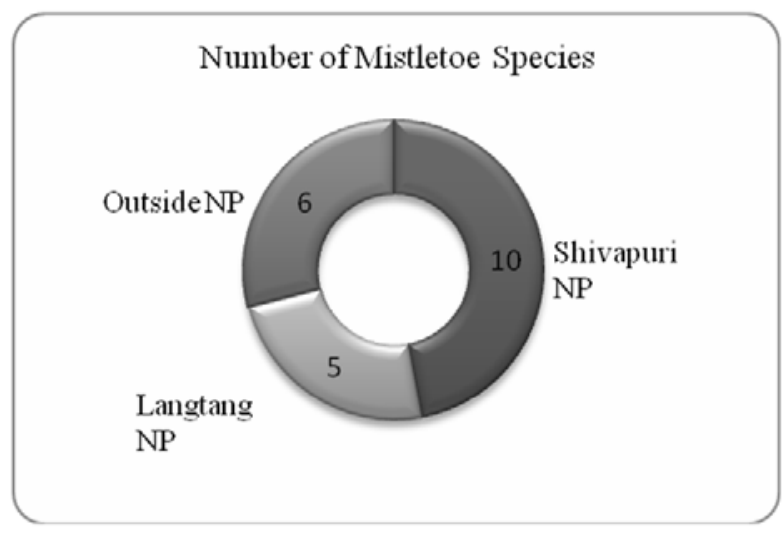

Fig 2: Number of mistletoe species
Similar to the previous studies in Nepal by Devkota and Acharya (1996), Devkota and Glatzel (2005), and Devkota and Kunwar (2006), the genus Scurrula (Loranthaceae) had the largest number of species: S. elata, S. pulverulenta, S. gracilifolia and S. parasitica. Scurrula genus was more aggressive than other genera in parasitizing a wide range of host plants of taxonomically unrelated families. Scurrula elata parasitized the highest number of 22 host plants (Fig 3). The Loranthaceae family was found parasitizing on a much wider range of host species than the Viscaceae family. A rare occurrence of $S$. elata was found parasitizing a Gymnosperm host, Pinus wallichiana; similarly, a case of hyperparasitism of $S$. gracilifolia was found on $S$. parasitica.

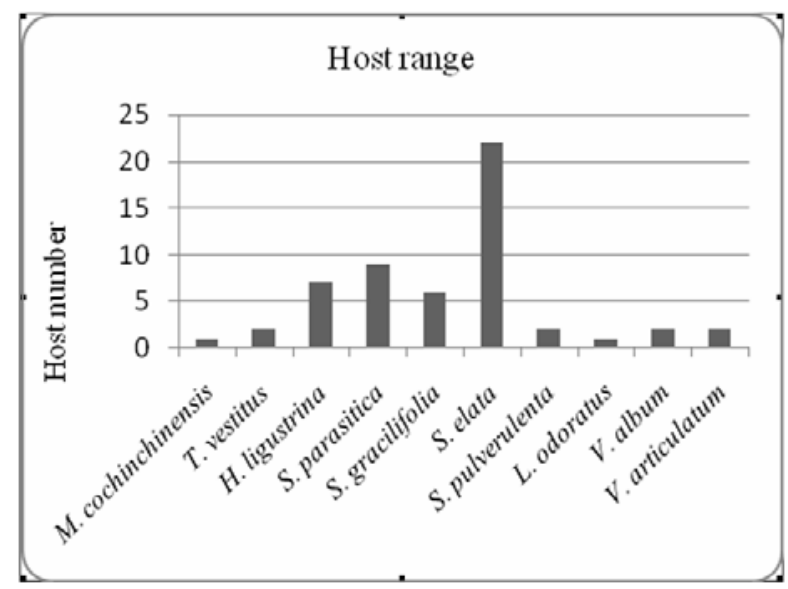

\section{Fig $3:$ Host number of each mistletoe species
Distribution patterns}

The distribution of mistletoe species did not demonstrate any uniformity because it was governed by multiple factors such as forest disturbance, climatic factors (light, temperature, and moisture), abundance and availability of dispersers and host species. Localized distribution pattern of mistletoes in warm and sunny slopes, forest edges and all along the trekking route was found to be similar to earlier reports in Nepal by Devkota and Acharya, 1996; Devkota and Glatzel, 2005; Devkota and Kunwar, 2006. These observations are also similar to those of Lavorel et al. (1999), Kelly et al. (2000) and Bach et al. (2005) who noted that marginal and fragmented forests not only provide better habitats for mistletoes but also promote invasion such habitats by mistletoes. Occurrences of many mistletoe species in open and warm habitats along all the trekking routes was also found to be suitable habitats for mistletoe birds and for dispersal by them as in New Zealand (Ladley and Kelley, 1996) and in Kathmandu Valley (Devkota and Acharya, 1996). Climatic factors were found to be important in determining mistletoe distribution in 
Table 1: Recorded host list of all mistletoe species

\section{Family Host species $\quad$ Mistletoe species}

Anacardiaceae Rhus javanica L. Mc Tr Lo Hi Sg Spa Spu Se Va Var No.

Berberidaceae Berberis asiatica Roxb. ex DC

Betulaceae Alnus nepalensis D. Don

Caprifoliaceae Viburnum erubescens Wall.

Cornaceae Benthamedia capitata (Wallich) Hara

Ericaceae Gaultheria fragrantissima Wall.

Lyonia ovalifolia Hort

Rhododendron arboreum $\mathrm{Sm}$.

Fagaceae Castanopsis tribuloides (Sm.) A. DC.

Quercus lanata Sm.

Quercus glauca Thunb.

Quercus semecarpifolia Sm.

Juglandaceae Juglans regia $\mathrm{L}$.

Labiateae Leucoseptrum canum Sm.

Loranthaceae Scurrula parasitica L.

Meliaceae Melia azederach L.

Moraceae Ficus bengalensis L.

Myricaceae Myrica esculenta Buch.-Ham.ex D. Don

Myrsinaceae Maesa chisia D. Don

Myrsine semiserrata Wall.

Myrsine capitellata Wall.

Oleaceae Ligustrum nepalense Wall.

Pinaceae Pinus wallichiana A. B. Jackson

Rosaceae Prunus cerasoides D. Don

Prunus cornuta (Wall. ex Royle) Steud.

Prunus domestica (L.) Schneid

Prunus persica (L.) Batsch

Pyrancantha crenulata (D. Don) Roem

Pyrus pashia Buch.-Ham. ex D. Don

Rutaceae Citrus limon (L.) Burm. f.

Zanthoxylum armatum DC.

Salicaceae Salix sp.

Symplocaceae Symplocos ramosissima Wall.

Theaceae Schima wallichii Choisy

Total number of parasitized host plants

$\begin{array}{llll}1 & 2 & 1\end{array}$

Mc: Macrosolen cochinchinensis, Tv: Taxillus vestitus, Lo: Loranthus odoratus, Hi: Helixanthera ligustrina

Sg: Scurrula gracilifolia, Spa: Scurrula parasitica, Spu: Scurrula pulverulenta, Se: Scurrula elata,

Va: Viscum album, Var: Viscum articulatum, No: Number of host species 
SNNP as many species were noticed on warm and sunny southern slopes of SNNP dominated by broadleaved forest below $2500 \mathrm{~m}$.

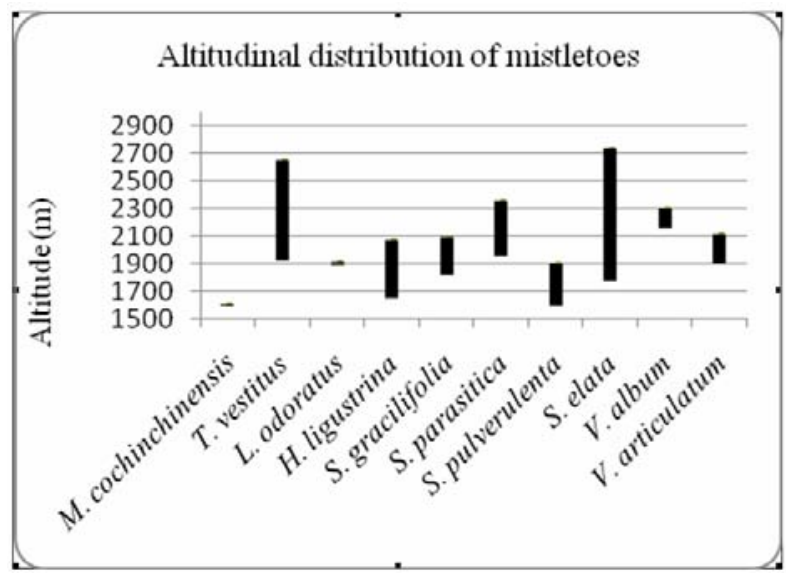

Fig 4: Altitudinal distribution pattern of mistletoe species

similar to the observation noted in Annapurna Area of Central Nepal by Devkota and Glatzel, 2005. $S$. elata was recorded over a wider vertical swath of about $1 \mathrm{~km}$ favoured by its widest host range. The distribution pattern of Scurrula species in the study area revealed an identical pattern of distribution of Scurrula species in Annapurna Conservation Area (Devkota and Glatzel, 2005). S. elata did not occur over $2800 \mathrm{~m}$, a habitat usually considered inhospitable to their avian dispersers. Devkota and Glatzel (2005) reported that cold and moist habitats above $3000 \mathrm{~m}$ in Nepal are generally considered unsuitable for mistletoe as such habitats are also avoided by mistletoe birds.

All ten mistletoe species were recorded in SNNP compared to only five species in LNP because SNNP is in the transition zone between sub-tropical and temperate vegetation zones and thus provides a wider range of hosts in a variety of habitats. SNNP also had more fragmented open canopy forests due to various anthropogenic disturbances and this wide variety of habitats favoured the growth of mistletoe according to similar observations of Lavorel et al. (1999) and Bach et al. (2005) in Australia and Kelly et al. (2000) in New Zealand.

Despite a wider climatic variation and vegetation composition ranging from sub-tropical to sub-alpine in LNP, the record of mistletoe species was less than SNNP. Taxillus vestitus, Scurrula elata, S. gracilifolia, S. parasitica and Viscum articulatum were the only five mistletoe species recorded in LNP. The reason for less mistletoe species diversity in LNP was due to intact vegetation in most areas of LNP that are undisturbed by human interferences because of their relative inaccessibility. Therefore, two reasons for less mistletoe species diversity in LNP maybe due to: 1) domination of conifer vegetation at higher elevation, providing less opportunity for Loranthaceae mistletoe to establish, and 2) little vegetation at higher elevation and extremely cold climatic condition, unsuitable for mistletoe and their avian dispersers.

Occurrence of higher number of mistletoe species (six) in unprotected area suggests that even the habitats outside the protected area can prove to be favourable mistletoe habitats. The trekking route between Magingoth and Chisapani traverses through unprotected area, passing through fragmented forest, orchards and the vegetation surrounding the agricultural fields. These human altered landscapes provide a suitable habitat for mistletoes to establish in such open habitats as per observations by Kujit, 1964; Calvin and Wilson, 1998; Lopez de Buen et al., 2002.

No habitats particularly rich in mistletoe diversity were found in either national parks. Some areas dominated by broadleaved forest in the warmer southern slopes of SNNP below 2500 m elevation sheltered habitats better suited for mistletoe establishment and growth.

Nepal's forests are facing severe stress due to the ever increasing demand for agricultural land, timber, fuelwood and fodder, and settlements. Deforestation and land degradation are serious problems in both protected and unprotected areas, and are thus major threats to mistletoe diversity. Both national parks were facing severe problems of timber harvest, fuelwood and fodder collection and encroachment of forest area for agricultural land. Increasing population has demanded new agricultural land and the increasing number of tourist have generated high demand for fuelwood in LNP for heating and cooking purpose.

\section{Conclusion}

Altogether ten mistletoe species were recorded along the trekking route within the protected and unprotected areas in the Central Nepal Himalayas. Despite being much smaller than Langtang National Park, Shivpuri Nagarjun National Park displayed higher mistletoe species diversity as all ten mistletoe species were recorded there. S. elata demonstrated 
both higher number of host species and a wider altitudinal distribution range. Distribution of mistletoe species was affected by climatic factors, forest edge, forest fragmentation, availability of suitable host species and behaviour of avian dispersers. Three species of mistletoes, previously unrecorded, have been added to the Flora of Langtang by this study. No specific habitats particularly rich in mistletoe diversity were identified in both the national parks, and it was observed that deforestation and land degradation were the major threats to mistletoe diversity in the study area.

\section{Acknowledgement}

The University Grants Commission, Kathmandu is duly acknowledged for supporting the study.

\section{References}

Abulfatih, H. A., and Emara. H. A. 1988. Altitudinal distribution of the hemiparasitic Loranthaceae in South Western Saudi Arabia. Biotropica 20: 81-83.

Bach, C. E., Kelly, D. and Hazlett, B. A. 2005. Forest edges benefit adults, but not seedlings, of the mistletoe Alepis flavida (Loranthaceae). Journal of Ecology 93: 79-86.

Calder, M. 1983. Mistletoes in focus: an introduction. In The Biology of Mistletoes, (eds.) Calder, M. and Bernhardt, P., Academic Press, Sydney, Australia, 1-18.

Calvin, C. and Wilson, C. 1998. Comparative morphology of haustoria within African Loranthaceae. In Mistletoes of Africa (eds) Polhill, R. and Weins D. The Royal Botanical Garden, Kew, London, UK, 17-36.

Devkota, M. P. and Acharya, N. 1996. Mistletoes (Loranthaceae and Viscaceae) in the Kathmandu valley, Nepal: altitudinal distribution, host trees, pollinators and seed dispersers. Acta Phytotaxonomica et Geobotanica 47 (2): 213-219.

Devkota, M. P. and Glatzel, G. 2005. Mistletoe of Annapurna Conservation Area, Central Nepal Himalayas. Journal of Japanese Botany 80 (1): 27-36.
Devkota, M. P. and Koirala, A. 2005. New record of mistletoe Viscum monoicum for the Nepal Himalayas. Journal of Japanese Botany 80 (1): 56.

Devkota, M. P. and Kunwar, R. M. 2006. Diversity, distribution and host range of mistletoes in Godawari-Phulchowki area, Kathmandu, Nepal. Journal of Japanese Botany 81: 255-261.

Devkota, M. P. and Joshi, G.P. 2008. Korthalsella japonica (Viscaceae): New record for the Nepal Himalayas, Ecoprint 15: 89-90.

Ganguly, P. and Kumar, N. C. 1976. Topographical distribution of the phanerogamic parasites in Sukna forest, Darjeeling District, West Bengal. Indian Forester 102: 459-462.

Hara, H., Stearn W. T., and Williams, L. H. J. 1978. An Enumeration of the Flowering Plants of Nepal. Vol I British Museum (Natural History), London, U.K.

Hara, H. L. and Williams, H. J. 1979. An Enumeration of the Flowering Plants of Nepal.Vol II British Museum (Natural History), Vol. II., London, U.K.

Hara, H., Charter, A. O., and Williams, L. H. J. 1982. An enumeration of flowering plants of Nepal. British Museum (Natural History), London, U.K.

Hawksworth, F. G. 1959. Distribution of dwarf mistletoes in relation to topography on the Mesacalaro Apache Reservation. New Mexico. Journal of Forestry 57: 919-922.

Hawksworth, F. G. 1983. Mistletoes as forest parasites. In The Biology of Mistletoes (eds) Calder, M. and Bernhardt, P., Academic Press. Sydney, Australia, 317-333.

Kelly, D., Ladley J. J., Robertson, A.W. and Norton, D. A. 2000. Limited forest fragmentation improves reproduction in the declining New Zealand mistletoe Peraxilla tetrapetala (Loranthaceae). In Genetics, demography and viability of fragmented population (eds) Young, A.G. and Clarke, G.), Cambridge University Press, Cambridge, U.K., 241-252. 
Koba, H. Akiyama, S., Endo, Y. and Ohba, H. 1994. Name List of the Flowering Plants and Gymnosperms of Nepal. The University Museum, the University of Tokyo, Tokyo, Japan.

Kujit, J. 1964. Critical observation on the parasitism of New World mistletoes. Canadian Journal of Botany 42: 1243-1287.

\section{Kujit, J. 1969. The Biology of Parasitic Flowering}

Plants. University California Press. Los Angeles, USA.

Ladley, J. J. and Kelley, D. 1996. Dispersal, germination and survival of New Zealand mistletoes (Loranthaceae): dependence on birds. New Zealand Journal of Ecology 20 (1): 69-79.

Lavorel, S., Smith, M. S. and Reid, N. 1999. Spread of mistletoes (Amyema preissii) in fragmented Australian woodlands: a simulation study. Landscape Ecology 14: 147-160.

Lopez de Buen, L., Ornelas, J. F., and Garcia Franco, J. G. 2002. Mistletoe infection of trees located at fragmented forest edges in the cloud forests of Central Veracruz, Mexico. Forest Ecology and Management 164: 293-302.
Malla, S. B., Shrestha, A. B., Rajbhandary, S.B., Shrestha, T. B., Adhikari, P.M. and Adhikari, S.R. 1976. Flora of Langtang and Cross Section Vegetation Survey, Department of Medicinal Plants, HMG/N. Kathmandu, Nepal.

Polhill, R., and Wiens, D. 1998 (eds.). Mistletoes of Africa. The Royal Botanic Garden, Kew, London, U.K.

Press, J. R., Shrestha, K. K., and Sutton, D. A. 2000. Annotated Checklist of the Flowering Plants of Nepal. The Natural History Museum, London, U.K.

Stearn, W. T. 1960. Allium and Milula in the Central and Eastern Nepal Himalaya. Bulletin of the British Museum, Natural History (Botany) 2: 159-191.

Xiao, L., and Pu, Z. 1988. An exploration of the Loranthaceae in Xishuanghanna. Acta Botanica Yunnanica 10: 69-78.

Zakaullah, M. and Khan, H. 1982. Survey and Control of Mistletoes in Pakistan. Pakistan Forest Institute, Annual Technical Report. Project PKFS-55.11, Peshawar, Pakistan. 